\title{
Corporate Entrepreneurship: A Review and Future Research Agenda
} Kamal Sakhdari

\author{
"A man who reviews the old so as to find out the new") \\ is qualified to teach others. \\ Confucius (551-479 BC) \\ Teacher, editor, politician, and philosopher
}

\begin{abstract}
The overarching theme of corporate entrepreneurship literature is to understand why some firms are able to generate higher levels of corporate entrepreneurship than others. While the extant literature has greatly advanced our understanding of entrepreneurial activities by established firms, less effort has been made to systematically review the literature to help us identify missing links and knowledge in prior studies. To address this gap, this article critically reviews previous important studies on corporate entrepreneurship and then develops a framework integrating previous research. Finally, the article suggests five potentially worthwhile avenues for future research.
\end{abstract}

\section{Introduction}

Corporate entrepreneurship refers to entrepreneurial activities, such as innovation, venturing, and strategic renewal, within existing firms (Zahra, 1996). The idea behind corporate entrepreneurship goes back to the mid-1970s. It was first introduced by Peterson and Berger (1971) as a strategy and leadership style adopted by large organizations to cope with the increasing level of market turbulence. It took until the early 1980s for corporate entrepreneurship to become a separate research topic through the works of Burgelman (1983) and Miller (1983), and in particular when Pinchot's (1985) book on intrapreneurship was published (Christensen, 2004).

Different labels have been used to address the phenomenon of entrepreneurship within established firms, such as corporate venturing (Burgelman, 1983), intrapreneurship (Pinchot 1985), corporate entrepreneurship (Guth \& Ginsberg, 1990), internal corporate entrepreneurship (Jones \& Butler, 1992) and strategic entrepreneurship (Hitt et al., 2011). Nevertheless, based on evidence from special issues of journals, it appears that corporate entrepreneurship has gained the most attention as the main construct (Guth \& Ginsberg, 1990; Phan et al., 2009). The considerable potential for corporate entrepreneurship to renew companies through innovation-based initiatives has led to increasing interest and research in how corporate entrepren- eurship can be perpetuated within established companies (Corbett et al., 2013).

Prior research on corporate entrepreneurship has attempted to clarify the scope of this construct, its antecedents and outputs, and the boundary conditions of these links. Yet, less effort has been devoted to reviewing and organizing previous studies to identify our knowledge gaps and valuable paths for future research. In this vein, this article aims to systematically review and organize prior research following several steps. The review was restricted to papers published in toptier journals spanning the period between January 1, 1990 and December 30, 2015. Several keywords were used to identify relevant articles including corporate entrepreneurship, intrapreneur, and organizational entrepreneurship. All relevant articles were identified and categorized using an integrative model. Under-investigated themes were also identified.

This article contributes to the corporate entrepreneurship literature by integrating prior studies on corporate entrepreneurship including the conceptualization, antecedents, and outputs. More importantly, it identifies missing links and knowledge in the extant literature and suggest paths for future research. The remainder of this article is structured as follows: first, the method is explained; then, the literature is critically reviewed and synthesized; finally, five future research paths are identified. 


\section{Corporate Entrepreneurship: A Review and Future Research Agenda}

\section{Kamal Sakhdari}

\section{Method}

Following Shepherd, Williams, and Patzelt (2015), criterion sampling was used based on keyword searches in top management and entrepreneurship journals such as Academy of Management Journal, Academy of Management Review, Administrative Science Quarterly, Journal of Management, Journal of Management Studies, Management Science, Organization Science, Strategic Management Journal, Journal of Business Research, Journal of Business Venturing, Entrepreneurship Theory and Practice, Strategic Entrepreneurship Journal, and Journal of Small Business Economics. The initial inventory included papers possessing the keywords of corporate entrepreneurship, intrapreneur, and organizational entrepreneurship in their title, abstract, or keywords, and spanning the period from 1989 to the end of 2015.

\section{Literature Review}

As shown in Figure 1, the relevant papers were categorized (discussed in the subsections below) into three main categories: i) papers conceptualizing corporate entrepreneurship, ii) papers about the antecedents of corporate entrepreneurship, which are categorized based on their levels of analysis entailing the team management, firm, network/dyad, and environment, and finally iii) papers focused on the outcomes of corporate entrepreneurship.

\section{Corporate entrepreneurship: conceptualization and dimensionality}

Scholars have endeavoured to define the corporate entrepreneurship domain over the last few decades. There were initially mixed views on the scope of corporate entrepreneurship because it was not clearly differentiated

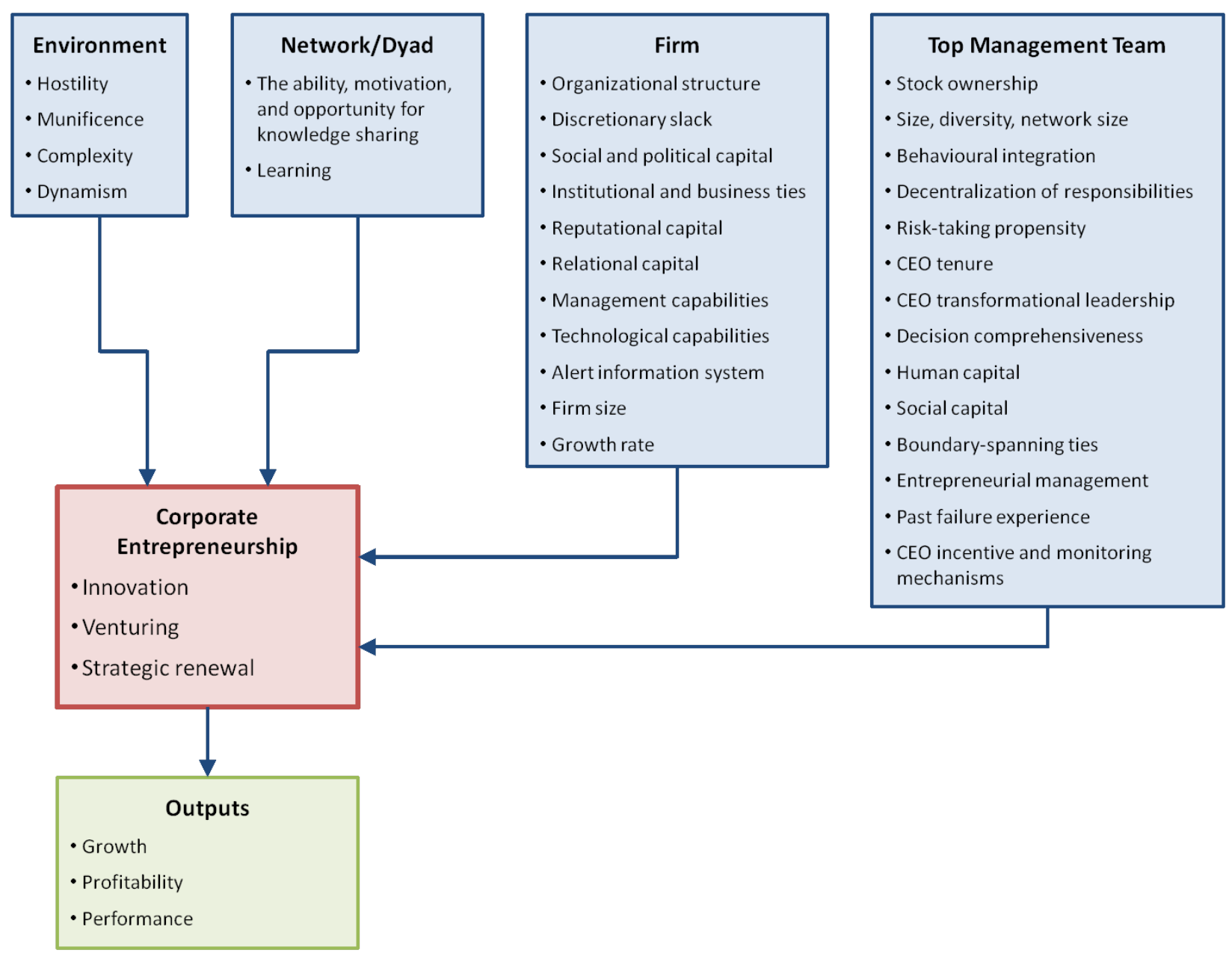

Figure 1. A model of corporate entrepreneurship's antecedents and outputs in the literature 


\section{Corporate Entrepreneurship: A Review and Future Research Agenda}

\section{Kamal Sakhdari}

from the common phenomenon of innovation or new product development in firms (Corbett et al., 2013). Guth and Ginsberg (1990) were among the first scholars attempting to clarify the domain by introducing two categories of corporate entrepreneurial activities, namely business venturing and strategic renewal. Business venturing refers to "the birth of new business within existing organizations," and strategic renewal is defined as "the transformation of organizations through renewal of the key ideas on which they are built" (Guth \& Ginsberg, 1990). Zahra (1996) then divides corporate entrepreneurship into three components of innovation, venturing, and strategic renewal. Innovation refers to "a company's commitment to creating and introducing products, production processes, and organizational systems". Venturing means "the firm will enter new businesses by expanding operations in existing or new markets." Strategic renewal concerns "revitalizing the company's operations by changing the scope of its business, its competitive approach, or both" (Zahra, 1996).

Other scholars have also categorized the domain of corporate entrepreneurship in different ways. However, the categories mostly lie within the three categories conceptualized by Zahra (1996). Covin and Miles (1999), for instance, propose four forms of corporate entrepreneurship entailing sustained regeneration, organizational rejuvenation, strategic renewal, and domain redefinition. Sustained regeneration refers to the continuous introduction of new products and services and new market entrance. Organizational rejuvenation is defined as changing internal processes, structures, or capabilities. Strategic renewal means the redefinition of a company's relationship with its markets and industry competitors by fundamentally changing the way it competes. These actions fundamentally reposition the firm in the market. Finally, domain redefinition is related to the creation of a new product-market arena that has not been recognized or actively exploited by other companies. Kuratko and Audretsch (2009) also add another category to the group: business model reconstruction. It refers to designing or redesigning a firm's core business model to enhance operational efficiencies or differentiate the company from its competitors in ways valued by the market. Similarly, Sharma and Chrisman (1999) define corporate entrepreneurship as "the processes whereby an individual or a group of individuals, in association with an existing organization, create a new organization or strategic renewal or innovation within that organization" They emphasize three main categories of corporate entrepreneurship encompassing corporate venturing, strategic renewal, and innovation in products and services.
Some scholars differentiate internal and external corporate venturing. In internal corporate venturing, new businesses reside within the internal boundaries of a firm, yet they may act as semi-autonomous entities (Morris et al., 2010). External venturing concerns "the creation of new businesses by corporations in which a corporation leverages external partners in an equity or non-equity inter-organizational relationship" (Schildt et al., 2005). Firms use governance modes such as corporate venture capital, non-equity alliance, joint ventures, and acquisitions for external corporate venturing. Corporate venture capital refers to the development of partnerships through investments in partners for financial and strategic purposes. Unlike corporate venture capital involving ownership in the relationship with partners, a non-equity alliance is concerned with the development of a new business with partners based on contracts. It also differs from joint ventures in that the latter leads to the formation of a new legal entity by partners for pursuing opportunities. Acquisition refers to the internalization of a new venture by purchasing the majority of the share capital of a venture (Schildt et al., 2005). Finally, licensing means gaining access to the knowledge, innovations, technologies, and discoveries of other firms in return for a fee (Yang et al., 2009).

Scholars also distinguish between domestic and international venturing (Yiu et al., 2007; Yiu \& Lau, 2008; Zahra et al., 2000). International venturing is related to a firm's venturing activities for exploiting entrepreneurial opportunities outside its home market (Zahra et al., 2004). Undertaking international venturing activities is considered to be more difficult than domestic venturing (Yiu et al., 2007; Zahra \& Hayton, 2008). This is mainly because firms in international markets are faced with the liability of foreignness arising from constraints, lack of knowledge of the target markets' institutional and business environments, and lack of legitimacy in foreign markets (Zaheer, 1995). International markets may also be more competitive than domestic markets (Etemad \& Wright, 2003), which may make international venturing more challenging in particular for firms operating in developing countries (Yiu et al., 2007). Despite the difficulties, globalization and the existence of entrepreneurial opportunities in international markets have stimulated companies to undertake international venturing and expand internationally (Zahra \& Hayton, 2008; Zahra et al., 2004).

Overall, the literature review shows that scholars have mainly focused on innovation, corporate venturing (domestic and international), and strategic renewal as the 


\section{Corporate Entrepreneurship: A Review and Future Research Agenda}

\section{Kamal Sakhdari}

main components of the corporate entrepreneurship construct. This construct has been used both as a single meta-construct (Bojica \& Fuentes, 2012; Heavey \& Simsek, 2013; Heavey et al., 2009; Ling et al., 2008; RomeroMartínez et al., 2010; Simsek, 2007; Simsek \& Heavey, 2011; Simsek et al., 2007; Simsek et al., 2009; Thorgren et al., 2012; Zhang et al., 2008) and as individual components (Yiu et al., 2007; Yiu \& Lau, 2008; Zahra et al., 2000) in the literature. Yet, it is mostly used as a single meta-construct because these dimensions are supposed to be different, but complementary and mutually supportive concepts. For example, renewing the competitive approach may increase the benefits of venturing activities, and new product development may make strategic renewal activities more beneficial (Heavey et al., 2009; Simsek, 2007; Simsek \& Heavey, 2011; Simsek et al., 2007). As such, "treating individual components of corporate entrepreneurship as independent ignores their potential complementarity" (Simsek \& Heavey, 2011).

Corporate entrepreneurship encompasses the actual entrepreneurial acts or market-oriented results, and differs from constructs such as entrepreneurial orientation, which are "predispositions of firms with respect to their strategy-making processes, practices, and activities," that stimulate corporate entrepreneurship ( Simsek \& Heavey, 2011; see also Dess \& Lumpkin, 2005). Intrapreneurship is more focused on the individual or team as intrapreneurs are defined as "those who take hands-on responsibility for creating innovation" (Sharma \& Chrisman, 1999; see also Pinchot, 1985).

\section{Corporate entrepreneurship: antecedents and outputs}

Studies show that corporate entrepreneurship can play an important role in achieving higher levels of corporate performance (Yiu \& Lau, 2008; Zahra, 1991, 1995), growth (Zahra, 1993; Zahra \& Covin, 1995), and profitability (Covin \& Slevin, 1991). A summary of the most important prior studies on the antecedents of corporate entrepreneurship is provided in Appendix 1. In terms of their level of analysis, as shown in Figure 1, these studies can be categorized into four groups:

1. Top management team (Behrens \& Patzelt, 2015; Glaser et al., 2015; Hayton, 2005; Heavey \& Simsek, 2013; Ling et al., 2008; Naldi et al., 2015; Simsek, 2007; Wang et al., 2015; Zahra, 1996; Zahra et al., 2000)

2. Firm (Behrens \& Patzelt, 2015; Kellermanns \& Eddleston, 2006; Nason et al., 2015; Simsek et al., 2009; Thorgren et al., 2012; Yiu et al., 2007; Yiu \& Lau, 2008)

\section{Network/dyad level (Turner \& Pennington III, 2015)}

4. Environment (Heavey et al., 2009; Romero-Martínez et al., 2010; Simsek et al., 2007; Zahra, 1991, 1993)

Previous research has mainly argued the origins of corporate entrepreneurship from the knowledge-based view (Grant, 1996), as summarized in Appendix 1. This view mainly considers knowledge as the most important and strategic resource in firms. The main premise of this theory is that corporate innovative activities are essentially a function of firms' capabilities to effectively combine and coordinate internal and external knowledge resources. Zahra (1991), for example, concludes that scanning, referring to formal efforts for collecting, analyzing, and interpreting data from the external environment, increases a firm's level of corporate entrepreneurship. Hayton (2005) argues that diversity of human capital in the top management team enhances corporate entrepreneurship by facilitating knowledge acquisition and triggering learning. Yiu and colleagues (2007) posit that firm-specific ownership advantages such as technological capabilities and business and institutional ties foster corporate entrepreneurship. Yiu and Lau (2008) suggest that a firm's political, social and reputational capital enhance the firm's engagement in corporate entrepreneurship. Simsek and colleagues (2009) argue that a company's alert information system increases corporate entrepreneurship by providing relevant information in a timely and pro-active manner. Thorgren and colleagues (2012) contend that relational capital among partners through knowledge transfer promotes corporate entrepreneurship. Finally, Heavey and Simsek (2013) conclude that the size, diversity, and network size of the top management team increase the level of corporate entrepreneurship.

\section{Discussion and Suggestions for Future Research}

The critical literature review reveals that, despite significant insights provided by prior research, as shown in Figure 2, future research can address the following five research avenues, which build on the existing theoretical lenses.

\section{Need for more capability-oriented models}

Prior studies have mainly focused on top management team characteristics and actions (Heavey \& Simsek, 2013; Ling et al., 2008; Simsek, 2007), structural factors (Burgers et al., 2009; Zahra, 1991), and business environment (Simsek et al., 2007; Zahra, 1993). This literature, however, has paid less attention to organizational 


\section{Corporate Entrepreneurship: A Review and Future Research Agenda}

\section{Kamal Sakhdari}

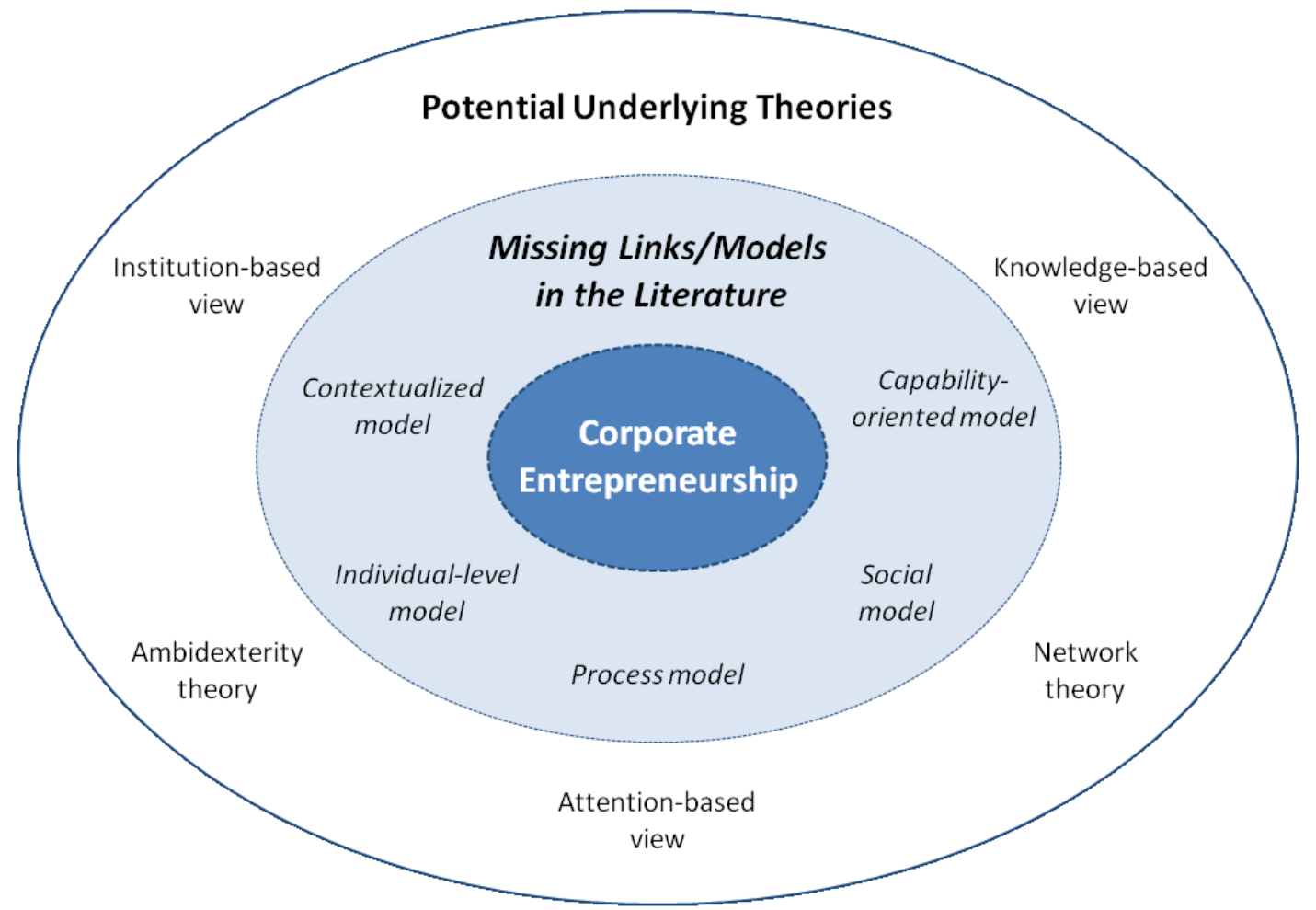

Figure 2. Potential paths for future research

capabilities. The need to build linkage between unpacked capabilities and corporate entrepreneurship has been reinforced in more recent reviews and studies (Phan et al., 2009; Yang et al., 2009). Capabilities refer to the ability of a firm to combine different resources together and make them conduct advantageous tasks and activities (Grant, 1991). They are also defined as "complex bundles of skills and accumulated knowledge, exercised through organizational processes that enable firms to coordinate activities and make use of their assets" (Day, 1994). As the building boxes of capabilities are organizational routines and processes (Sarkar et al., 2009), they can better tease apart corporate practices though which firms can enhance their rate of corporate entrepreneurial activities. In particular, one of the main challenges firms face in undertaking corporate entrepreneurship is the generation of new knowledge (Teng, 2007; Zahra et al., 2009). Corporate entrepreneurship relies on new knowledge for doing things differently, or doing different things, manifesting in the forms of innovation in products and services, processes, systems, strategies, and markets (Teng, 2007). As such, knowledge-based capabilities, such as absorptive capacity (Zahra, 2015) or networking capabilities (Sakhdari et al., 2014a), for acquisition, integration, development, and exploitation of new knowledge can be as well important as the structural factors, dominant in the literature, in explaining why some firms are more entrepreneurial than others. Moreover, corporate entrepreneurship is vying with ongoing business operations for catching corporate attention (Burgelman \& Valikangas, 2005). Thus, from an attention-based view (Ocasio, 1997), a channelling mechanism to focus organizational capabilities on corporate entrepreneurship may be necessary (Sakhdari et al., 2014b) but is less theorized in the literature.

\section{Need for more social models}

Given that corporate entrepreneurial outputs are knowledge-intensive, firms need to develop new knowledge for pursuing corporate entrepreneurship (Teng, 2007). Scholars have traditionally focused on internal development of knowledge (Brouwer et al., 1993; Hoskisson \& Hitt, 1988). However, internal development of new knowledge is accompanied by high resource and development expenses, high levels of risk, and timing issues (Eisenhardt \& Schoonhoven, 1996; Teng, 2007). Recently, scholars have suggested sourcing new knowledge from other players in the market such as suppliers, customers, research centres, and competitors as a complementary and effective approach for companies pursuing corporate entrepreneurship (Sim- 


\section{Corporate Entrepreneurship: A Review and Future Research Agenda}

\section{Kamal Sakhdari}

sek et al., 2003; Teng, 2007; Zahra et al., 2009). This research stream, which has recently gained more prominence, posits that innovative activities are mainly a function of firms' capabilities to effectively combine internal and external knowledge resources (Chesbrough, 2003; Grant, 1996; Kogut \& Zander, 1992).

In this vein, scholars have addressed the importance of partnering relationships for filling a firm's knowledge gaps and undertaking corporate entrepreneurship. Yiu and colleagues (2007), for example, suggest that network ties with customers enhance corporate entrepreneurship and international venturing activities in firms. Rothaermel and Deeds (2006) contend that prior network experience helps firms to better benefit from their network ties for innovative activities. Researchers have also investigated the role of key players' social capital in external knowledge sourcing and the pursuit of corporate entrepreneurship. Heavey and Simsek (2013), for instance, show that the network size of top management teams has a positive impact on corporate entrepreneurship.

Prior studies hint at the importance of inter-firm relationships and external knowledge access in fostering corporate entrepreneurship. This literature, however, has adopted a static approach, and has done little to unpack networking capabilities for the formation and management of partnering relationships (Sarkar et al., 2009). Moreover, empirical results are mixed with regard to the impact of the number of business partners on corporate entrepreneurial activities, in particular in the context of developing countries and among smaller firms (Lin et al., 2014; Yiu \& Lau, 2008; Wu, 2011). As such, investigating organizational and contextual moderators can be a compelling path for future research (Sakhdari \& Farsi, 2016). Finally, recent studies have adopted a network/dyad level of analysis and argued how mechanisms for sharing knowledge in an organizational network can enhance corporate entrepreneurship (Turner \& Pennington III, 2015). The literature lacks insights into how and why different sources of knowledge can be integrated (Kogut \& Zander, 1992) at a network level to enhance corporate entrepreneurial activities. For example, Dyer and Hatch (2006) indicate that firm mechanisms for sharing knowledge with partners differentiate innovative performance of firms involved in different networks.

\section{Need for contextualization}

Institutions are formal (rules and regulations) and informal (norms and values) frameworks that affect the behaviour of individuals and firms by determining the rules of the game (Peng, 2009). Apart from industry conditions and corporate capabilities, according to the industry-based perspective (Porter, 1980) and resource-based view (Barney, 1991), a firm's behaviour is also a reflection of its institutional frameworks or contexts. These frameworks can constrain or (if well developed) facilitate human and corporate behaviours (Peng, 2003; Peng et al., 2009). Institutional contexts vary based on their levels of market orientation or development. Institutional market orientation refers to the extent to which an institutional context adheres to freemarket policies (Shinkle et al., 2013), as measured by the level of freedom in such areas as trade, investment, financial, business operations, and property rights (Kane et al., 2007).

Scholars have recently argued for the importance of different levels of institutional market orientation in action-output relationships. This stream of research suggests that firms need different capabilities and strategies for rationally pursuing their interests in different contexts with distinctive levels of institutional market orientation (Lin et al., 2009; Luk et al., 2008; Peng, 2003; Peng \& Heath, 1996; Shinkle et al., 2013; Shinkle \& McCann, 2014). Yet, less effort has been made in the literature of corporate entrepreneurship to contextualize corporate entrepreneurial activities. Yiu and Lau (2008), for instance, do not reach significant results for the impact of the number of network ties on corporate entrepreneurial activities in the contexts of developing countries and call for future research to further investigate these connections in the context of developing contexts. Similarly, more recent studies suggest that researchers should contextualize theorizing in entrepreneurship (Bruton et al., 2008; Hitt et al., 2011; Welter, 2011; Zahra, 2007) to highlight the boundary conditions of merging theories and models across different institutional contexts. Sakhdari, Burgers, and Davidsson (2014), for example, indicate that the impact of a firm's absorptive capacity on corporate entrepreneurship can be subject to the firm's institutional context.

\section{Need for more process models}

The literature on corporate entrepreneurship lacks process models of corporate entrepreneurial activities. There are two general approaches to corporate entrepreneurship. The first one is an output-oriented approach considering corporate entrepreneurship as a number of market results such as innovation in products and services and venturing (Simsek, 2007; Zahra, 1996). This approach, which is more dominant in the literature, is consistent with the common defini- 


\section{Corporate Entrepreneurship: A Review and Future Research Agenda}

\section{Kamal Sakhdari}

tion of entrepreneurship as "new entry" (Davidsson, 2004; Wales et al., 2015). The second approach considers corporate entrepreneurship as a process entailing different phases (Burgelman, 1983; Hornsby et al., 1993). Process models can better tease apart the needed steps to enhance the levels of corporate entrepreneurship. Yet, there are very few process models explaining the process of corporate entrepreneurship. In particular, less effort has been devoted to theorizing the process of sub-dimensions of corporate entrepreneurship such as venturing and strategic renewal. For example, one of the rare process models of venturing is suggested by Burgelman (1983), and there is a dearth of research on process models of corporate entrepreneurship.

\section{Need for more individual-level research}

Although corporate entrepreneurship is in essence a firm-level construct, it manifests itself in the actions and behaviours of employees (Ren \& Guo, 2011; Stevenson \& Jarillo, 1990). In his seminal paper, Burgelman (1983) posits that corporate entrepreneurship mainly results from entrepreneurial behaviours undertaken by employees at lower levels of companies. Yet, surprisingly less attention has been given to the organizational mechanisms enabling firms to better stimulate entrepreneurial behaviours by their employees. In this vein, one path for future research can be investigating factors encouraging employees to disclose their underground ideas (Sakhdari \& Bidakhavidi, 2016). Individuals at lower levels of firms, such as those operating in R\&D departments, tend to undertake bootlegging behaviour to reduce uncertainty associated with their ideas (Masoudnia \& Szwejczewski, 2012), show the technological and market potential of their ideas (Criscuolo et al., 2013), and establish legitimacy for subsequent resource acquisition (Kannan-Narasimhan, 2014). How firms can utilize the underground behaviours for corporate entrepreneurship is under-investigated in the literature of corporate entrepreneurship.

Another potential avenue for future studies is the way firms can mitigate exploration-exploitation tension at individual levels (Gibson \& Birkinshaw, 2004). Indeed, a basic tension firms face is whether to attend their employees towards exploratory activities for future viability or in exploitative activities to ensure existing viability (March, 1991; Van de Ven \& Engleman, 2004). Exploratory activities are mainly related to the development of new knowledge and capabilities whereas the exploitative operations are more concerned with the utilization of current capabilities and stock of knowledge (Katila \& Ahuja, 2002). These activities are competing with each other for organizational attention (Burgelman \& Valikangas, 2005; Burgelman, 1983). Yet, firms need both exploratory and exploitative activities for higher performance and innovative activities: the socalled ambidextrous firms (Raisch et al., 2009; Jansen et al., 2005). Indeed, although exploration and exploitation can be viewed as trade-offs for firms (Gupta et al., 2006), the dominant view is that such activities are distinct, yet complementary, modes of activity (Hill \& Birkinshaw, 2014). Accordingly, attention management concerning the allocation of employees' efforts and attention towards both exploratory and exploitative operations is proposed as the most essential step for boosting corporate entrepreneurship (Ren \& Guo, 2011; Van de Ven, 1986). Yet, surprisingly less attention has been given to the contextual mechanisms enabling firms to mitigate the tension between exploration and exploitation at individual levels, which can be a compelling path for future research.

\section{Conclusion}

Overall, the literature review presented in this article reveals that, despite a large body of informative research on corporate entrepreneurship, there is a dearth of research on more capability-oriented, social, contextualized, and process models and individual-level research of corporate entrepreneurship. The suggested paths for future research presented here may provide interesting insights into why some firms are more entrepreneurial than others.

\section{About the Author}

Kamal Sakhdari is an Assistant Professor in the Faculty of Entrepreneurship at the University of Tehran, Iran. He received his $\mathrm{PhD}$ in Business and Entrepreneurship from the Queensland University of Technology (QUT) in Brisbane, Australia. His main research interests are corporate entrepreneurship, innovation management, institutional theory, and international business. He is also a member of the Australian Centre for Entrepreneurship Research (ACE) at the QUT Business School. 


\section{Corporate Entrepreneurship: A Review and Future Research Agenda}

\section{Kamal Sakhdari}

\section{References}

Barney, J. 1991. Firm Resources and Sustained Competitive Advantage. Journal of Management, 17(1): 99-120. http://dx.doi.org/10.1177/014920639101700108

Behrens, J., \& Patzelt, H. 2015. Corporate Entrepreneurship Managers' Project Terminations: Integrating Portfolio-Level, Individual-Level, and Firm-Level Effects. Entrepreneurship Theory and Practice, 40(4): 815-842.

http://dx.doi.org/10.1111/etap.12147

Bojica, A. M., \& Fuentes, M. D. M. F. 2012. Knowledge Acquisition and Corporate Entrepreneurship: Insights from Spanish SMEs in the ICT Sector. Journal of World Business, 47(3): 397-408. http://dx.doi.org/10.1016/j.jwb.2011.05.007

Brouwer, E., Kleinknecht, A., \& Reijnen, J. O. 1993. Employment Growth and Innovation at the Firm Level. Journal of Evolutionary Economics, 3(2): 153-159. http://dx.doi.org/10.1007/BF01213832

Bruton, G. D., Ahlstrom, D., \& Obloj, K. 2008. Entrepreneurship in Emerging Economies: Where Are We $t \backslash$ Today and Where Should the Research Go in the Future? Entrepreneurship Theory and Practice, 32(1): 1-14. http://dx.doi.og/10.1111/j.1540-6520.2007.00213.x

Burgelman, R. A. 1983. A Process Model of Internal Corporate Venturing in the Diversified Major Firm. Administrative Science Quarterly, 28(2): 223-244. http://dx.doi.org/10.2307/2392619

Burgelman, R. A., \& Valikangas, L. 2005. Venturing Cycles. MIT Sloan Management Review, 46(4): 26-34.

Burgers, J. H., \& Covin, J. G. 2014. The Contingent Effects of Differentiation and Integration on Corporate Entrepreneurship. Strategic Management Journal, 37(3): 521-540. http://dx.doi.org/10.1002/smj.2343

Chesbrough, H. W. 2003. Open Innovation: The New Imperative for Creating and Profiting from Technology. Boston, MA: Harvard Business School Publishing.

Christensen, K. S. 2004. A Classification of the Corporate Entrepreneurship Umbrella: Labels and Perspectives. International Journal of Management and Enterprise Development, 1(4): 301-315.

http://dx.doi.org/10.1504/IJMED.2004.004635

Corbett, A., Covin, J. G., O'Connor, G. C., \& Tucci, C. L. 2013. Corporate Entrepreneurship: State-of-the-Art Research and a Future Research Agenda. Journal of Product Innovation Management, 3(5): 812-820.

http://dx.doi.org/10.1111/jpim.12031

Covin, J. G., \& Miles, M. 1999. Corporate Entrepreneurship and the Pursuit of Competitive Advantage. Entrepreneurship Theory and Practice, 23: 47-64.

Covin, J. G., \& Slevin, D. P. 1991. A Conceptual Model of Entrepreneurship as Firm Behaviour. Entrepreneurship Theory and Practice, 16: 7-25.

Criscuolo, P., Salter, A., \& Ter Wal, A. L. 2013. Going Underground: Bootlegging and Individual Innovative Performance. Organization Science, 25(5): 1287-1305.

http://dx.doi.org/10.1287/orsc.2013.0856
Davidsson, P. 2004. Researching Entrepreneurship. New York, NY: Springer Verlag.

Day, G. S. 1994. The Capabilities of Market-Driven Organizations. The Journal of Marketing, 58(4): 37-52. http://dx.doi.org/10.2307/1251915

Dyer, J. H., \& Hatch, N. W. 2006. Relation-Specific Capabilities and Barriers to Knowledge Transfers: Creating Advantage through Network Relationships. Strategic Management Journal, 27(8): 701-719. http://dx.doi.org/10.1002/smj.543

Dess, G. G., \& Lumpkin, G. T. 2005. The Role of Entrepreneurial Orientation in Stimulating Effective Corporate Entrepreneurship. The Academy of Management Executive, 19(1): 147-156. http://dx.doi.org/10.5465/AME.2005.15841975

Eisenhardt, K. M., \& Schoonhoven, C. B. 1996. Resource-Based View of Strategic Alliance Formation: Strategic and Social Effects in Entrepreneurial Firms. Organization Science, 7(2): 136-150. http://dx.doi.org/10.1287/orsc.7.2.136

Etemad, H., \& Wright, R. W. 2003. Internationalization of SMEs: Toward a New Paradigm. Small Business Economics, 20(1): 1-4. http://www.jstor.org/stable/40229246

Gibson, C. B., \& Birkinshaw, J. 2004. The Antecedents, Consequences, and Mediating Role of Organizational Ambidexterity. Academy of Management Journal, 47(2): 209-226. http://dx.doi.org/10.2307/20159573

Glaser, L., Fourné, S. P., \& Elfring, T. 2015. Achieving Strategic Renewal: The Multi-Level Influences of Top and Middle Managers' Boundary-Spanning. Small Business Economics, 45(2): 305-327. http://dx.doi.org/10.1007/s11187-015-9633-5

Grant, R. M. 1996. Toward a Knowledge-Based Theory of the Firm. Strategic Management Journal, 17(2): 109-122. http://dx.doi.org/10.1002/smj.4250171110

Gupta, A., Smith, K. G., \& Shalley, C. A. 2006. The Interplay Between Exploration and Exploitation. Academy of Management Journal, 49(4): 693-706. http://dx.doi.org/10.5465/AMJ.2006.22083026

Guth, W., \& Ginsberg, A. 1990. Guest Editor's Introduction. Strategic Management Journal, 11: 5-15.

http://www.jstor.org/stable/2486666

Hayton, J. C. 2005. Competing in the New Economy: The Effect of Intellectual Capital on Corporate Entrepreneurship in HighTechnology New Ventures. R\&D Management, 35(2): 137-155. http://dx.doi.org/10.1111/j.1467-9310.2005.00379.x

Heavey, C., \& Simsek, Z. 2013. Top Management Compositional Effects on Corporate Entrepreneurship: The Moderating Role of Perceived Technological Uncertainty. Journal of Product Innovation Management, 46(8): 1289-1314. http://dx.doi.org/10.1111/jpim.12033

Heavey, C., Simsek, Z., Roche, F., \& Kelly, A. 2009. Decision Comprehensiveness and Corporate Entrepreneurship: The Moderating Role of Managerial Uncertainty Preferences and Environmental Dynamism. Journal of Management Studies, 46(8): 1289-1314.

http://dx.doi.org/10.1111/j.1467-6486.2009.00858.x 


\section{Corporate Entrepreneurship: A Review and Future Research Agenda}

\section{Kamal Sakhdari}

Hill, S. A., \& Birkinshaw, J. 2014. Ambidexterity and Survival in Corporate Venture Units. Journal of Management, 40(7): 1899-1931.

http://dx.doi.org/10.1177/0149206312445925

Hitt, M. A., Ireland, R. D., Sirmon, D. G., \& Trahms, C. A. 2011. Strategic Entrepreneurship: Creating Value for Individuals, Organizations, and Society. The Academy of Management Perspectives, 25(2), 57-75.

Hoskisson, R. E., \& Hitt, M. A. 1988. Strategic Control Systems and Relative R\&D Investment in Large Multiproduct Firms. Strategic Management Journal, 9(6): 605-621.

http://dx.doi.org/10.1002/smj.4250090607

Hornsby, J. S., Naffziger, D. W., Kuratko, D. F., \& Montagno, R. V. 1993. An Interactive Model of the Corporate Entrepreneurship Process. Entrepreneurship Theory and Practice, 17(2): 29-38.

Jansen, J. J., Van Den Bosch, F. A., \& Volberda, H. W. 2005. Managing Potential and Realized Absorptive Capacity: How Do Organizational Antecedents Matter? The Academy of Management Journal, 48(6): 999-1015.

http://dx.doi.org/10.5465/AMJ.2005.19573106

Jansen, J. J. P., Van Den Bosch, F. A. J., \& Volberda, H. W. 2006. Exploratory Innovation, Exploitative Innovation, and Performance: Effects of Organization Antecedents and Environmental Moderators. Management Science, 52(11): 1661-1674. http://dx.doi.org/10.1287/mnsc.1060.0576

Jones, G. R., \& Butler, J. E. 1992. Managing Internal Corporate Entrepreneurship: An Agency Theory Perspective. Journal of Management, 18(4): 733-749.

http://dx.doi.org/10.1177/014920639201800408

Kane, T., Holmes, K. R., \& O'Grady, M. A. 2007. 2007 Index of Economic Freedom. Washington, DC: Heritage Foundation.

Kannan-Narasimhan, R. P. 2014. Organizational Ingenuity in Nascent Innovations: Gaining Resources and Legitimacy through Unconventional Actions. Organization Studies, 35(4): 483-509. http://dx.doi.org/10.1177/0170840613517596

Katila, R., \& Ahuja, G. 2002. Something Old, Something New: A Longitudinal Study of Search Behaviour and New Product Introduction. Academy of Management Journal, 45(6): 1183-1195. http://dx.doi.org/10.2307/3069433

Kellermanns, F. W., \& Eddleston, K. A. 2006. Corporate Entrepreneurship in Family Firms: A Family Perspective. Entrepreneurship Theory and Practice, 30(6): 809-830. http://dx.doi.org/10.1111/j.1540-6520.2006.00153.x

Kogut, B., \& Zander, U. 1992. Knowledge of the Firm, Combinative Capabilities, and the Replication of Technology. Organization Science, 3(3): 383-397. http://www.jstor.org/stable/2635279

Kuratko, D. F., \& Audretsch, D. B. 2009. Strategic Entrepreneurship: Exploring Different Perspectives of an Emerging Concept. Entrepreneurship Theory and Practice, 33(1): 1-17. http://dx.doi.org/10.1111/j.1540-6520.2008.00278.x

Lin, Y. H., Chen, C. J., \& Lin, B. W. 2014. The Roles of Political and Business Ties in New Ventures: Evidence from China. Asian Business \& Management, 13(5): 411-440. http://dx.doi.org/10.1057/abm.2014.14
Lin, Z. J., Peng, M. W., Yang, H., \& Sun, S. L. 2009. How Do Networks and Learning Drive M\&As? An Institutional Comparison between China and the United States. Strategic Management Journal, 30(10): $1113-1132$.

http://dx.doi.org/10.1002/smj.777

Ling, Y., Simsek, Z., Lubatkin, M. H., \& Veiga, J. F. 2008. Transformational Leadership's Role in Promoting Corporate Entrepreneurship: Examining the CEO-TMT Interface. Academy of Management Journal, 51(3): 557-576. http://dx.doi.org/10.5465/AMJ.2008.32626023

Luk, C.-L., Yau, O. H., Sin, L. Y., Tse, A. C., Chow, R. P., \& Lee, J. S. 2008. The Effects of Social Capital and Organizational Innovativeness in Different Institutional Contexts. Journal of International Business Studies, 39(4): 589-612.

http://dx.doi.org/10.1057/palgrave.jibs.8400373

March, J. G. 1991. Exploration and Exploitation in Organizational Learning. Organization Science, 2(1): 71-87. http://dx.doi.org/10.1287/orsc.2.1.71

Masoudnia, Y., \& Szwejczewski, M. 2012. Bootlegging in the R\&D Departments of High-Technology Firms. Research-Technology Management, 55(5): 35-42.

http://dx.doi.org/10.5437/08956308X5505070

Miller, D. 1983. The Correlates of Entrepreneurship in Three Types of Firms. Management Science, 29(7): 770-791. http://dx.doi.org/10.1287/mnsc.29.7.770

Morris, M. H., Kuratko, D. F., \& Covin, J. G. 2010. Corporate Entrepreneurship and Innovation: Entrepreneurial Development within Organizations. Mason, OH: South-Western Cengage Learning.

Naldi, L., Achtenhagen, L., \& Davidsson, P. 2015. International Corporate Entrepreneurship among SMEs: A Test of Stevenson's Notion of Entrepreneurial Management. Journal of Small Business Management, 53(3): 780-800.

http://dx.doi.org/10.1111/jsbm.12087

Nason, R. S., McKelvie, A., \& Lumpkin, G. T. 2015. The Role of Organizational Size in the Heterogeneous Nature of Corporate Entrepreneurship. Small Business Economics, 45(2): 279-304. http://dx.doi.org/10.1007/s11187-015-9632-6

Ocasio, W. 1997. Towards an Attention-Based View of the Firm. Strategic Management Journal, 18(S1): 187-206. http://dx.doi.org/10.1002/(SICI) 1097-0266(199707)18:1+<187::AIDSMJ936>3.0.CO;2-K

Peng, M. W. 2003. Institutional Transitions and Strategic Choices. The Academy of Management Review, 28(2): 275-296. http://dx.doi.org/10.5465/AMR.2003.9416341

Peng, M. W. 2009. Global Strategy (2nd ed.). Cincinnati, OH: SouthWestern Cengage Learning.

Peng, M. W., \& Heath, P. S. 1996. The Growth of the Firm in Planned Economies in Transition: Institutions, Organizations, and Strategic Choice. Academy of Management Review, 21(2): 492-528. http://dx.doi.org/10.5465/AMR.1996.9605060220

Peng, M. W., Sunny, L. S., Brian, P., \& Hao, C. 2009. The InstitutionBased View as a Third Leg for a Strategy Tripod. The Academy of Management Perspectives, 23(3): 63-81. http://dx.doi.org/10.5465/AMP.2009.43479264 


\section{Corporate Entrepreneurship: A Review and Future Research Agenda}

\section{Kamal Sakhdari}

Peterson, R. A., \& Berger, D. G. 1971. Entrepreneurship in Organizations: Evidence from the Popular Music Industry. Administrative Science Quarterly, 16(1): 97-106.

Phan, P. H., Wright, M., Ucbasaran, D., \& Tan, W.-L. 2009. Corporate Entrepreneurship: Current Research and Future Directions. Journal of Business Venturing, 24(3): 197-205. http://dx.doi.org/10.1016/j.jbusvent.2009.01.007

Pinchot , G. 1985. Intrapreneuring: Why You Don't Have to Leave the Corporation to Become an Entrepreneur. New York, NY: Harper \& Row.

Porter, M. E. 1980. Competitive Strategy. New York: Free Press.

Raisch, S., Birkinshaw, J., Probst, G., \& Tushman, M. L. 2009. Organizational Ambidexterity: Balancing Exploitation and Exploration for Sustained Performance. Organization Science, 20(4): 685-695.

http://dx.doi.org/10.1287/orsc.1090.0428

Ren, C. R., \& Guo, C. 2011. Middle Managers' Strategic Role in the Corporate Entrepreneurial Process: Attention-Based Effects. Journal of Management, 37(6): 1586-1610.

http://dx.doi.org/10.1177/0149206310397769

Romero-Martínez, A. M., Fernández-Rodríguez, Z., \& VázquezInchausti, E. 2010. Exploring Corporate Entrepreneurship in Privatized Firms. Journal of World Business, 45(1): 2-8. http://dx.doi.org/10.1016/j.jwb.2009.04.008

Rothaermel, F. T., \& Deeds, D. L. 2006. Alliance Type, Alliance Experience and Alliance Management Capability in HighTechnology Ventures. Journal of Business Venturing, 21(4): 429-460.

http://dx.doi.org/10.1016/j.jbusvent.2005.02.006

Sakhdari, K., \& Bidakhavidi, E. J. 2016. Underground Innovation: How to Encourage Bootlegging Employees to Disclose their Good Ideas. Technology Innovation Management Review, 6(3): 5-12. http://timreview.ca/article/970

Sakhdari, K., Burgers, H., \& Davidsson, P. 2014a. Unpacking the Networking Capabilities and Corporate Entrepreneurship Relationship. In Academy of Management Proceedings, 2014(1): 13260. http://dx.doi.org/10.5465/AMBPP.2014.13260abstract

Sakhdari, K., Burgers, H., \& Davidsson, P. 2014b. Capable but Not Able: The Effect of Institutional Context and Search Breadth on the Absorptive Capacity-Corporate Entrepreneurship Relationship. In Proceedings of the Australian Centre for Entrepreneurship Research Exchange Conference 2014: 954-974. Brisbane, Australia: Queensland University of Technology.

Sakhdari, K., Burgers, H., \& Davidsson, P. 2014. The Moderating Role of Entrepreneurial Management in the Relationship between Absorptive Capacity and Corporate Entrepreneurship: An Attention-Based View. In Proceedings of the Australian Centre for Entrepreneurship Research Exchange Conference 2014: 975-994. Brisbane, Australia: Queensland University of Technology.

Sakhdari, K., \& Farsi, J.Y. 2016. Business Partners and Corporate Entrepreneurship in Developing Countries. International Journal of Management and Enterprise Development, 15(1): 61-77. http://dx.doi.org/10.1504/IJMED.2016.075875

Sarkar, M. B., Aulakh, P. S., \& Madhok, A. 2009. Process Capabilities and Value Generation in Alliance Portfolios. Organization Science, 20(3): 583-600.

http://dx.doi.org/10.1287/orsc. 1080.0390
Schildt, H. A., Maula, M. V., \& Keil, T. 2005. Explorative and Exploitative Learning from External Corporate Ventures. Entrepreneurship Theory and Practice, 29(4): 493-515. http://dx.doi.org/10.1111/j.1540-6520.2005.00095.x

Sharma, P., \& Chrisman, S. J. J. 1999. Toward a Reconciliation of the Definitional Issues in the Field of Corporate Entrepreneurship. Entrepreneurship Theory and Practice, 23(3): 11-27.

Shepherd, D. A., Williams, T. A., \& Patzelt, H. 2015. Thinking about Entrepreneurial Decision Making Review and Research Agenda. Journal of Management, 41(1): 11-46. http://dx.doi.org/10.1177/0149206314541153

Shinkle, G. A., Kriauciunas, A. P., \& Hundley, G. 2013. Why Pure Strategies May Be Wrong for Transition Economy Firms. Strategic Management Journal, 34(10): 1244-1254.

http://dx.doi.org/10.1002/smj.2060

Shinkle, G. A., \& McCann, B. T. 2014. New Product Deployment: The Moderating Influence of Economic Institutional Context. Strategic Management Journal, 35(7): 1090-1101.

http://dx.doi.org/10.1002/smj.2132

Simsek, Z. 2007. CEO Tenure and Organizational Performance: An Intervening Model. Strategic Management Journal, 28(6): 653-662. http://dx.doi.org/10.1002/smj.599

Simsek, Z., \& Heavey, C. 2011. The Mediating Role of Knowledge-Based Capital for Corporate Entrepreneurship Effects on Performance: A Study of Small- to Medium-Sized Firms. Strategic Entrepreneurship Journal, 5(1): 81-100. http://dx.doi.org/10.1002/sej.108

Simsek, Z., Lubatkin, M. H., \& Floyd, S. W. 2003. Inter-Firm Networks and Entrepreneurial Behaviour: A Structural Embeddedness Perspective. Journal of Management, 29(3): 427-442. http://dx.doi.org/10.1016/S0149-2063_03_00018-7

Simsek, Z., Lubatkin, M. H., Veiga, J. F., \& Dino, R. N. 2009. The Role of an Entrepreneurially Alert Information System in Promoting Corporate Entrepreneurship. Journal of Business Research, 62(8): 810-817. http://dx.doi.org/10.1016/j.jbusres.2008.03.002

Simsek, Z., Veiga, J. F., \& Lubatkin, M. H. 2007. The Impact of Managerial Environmental Perceptions on Corporate Entrepreneurship: Towards Understanding Discretionary Slack's Pivotal Role. Journal of Management Studies, 44(8): 1398-1424. http://dx.doi.org/10.1111/j.1467-6486.2007.00714.x

Stevenson, H. H., \& Jarillo, J. C. 1990. A Paradigm of Entrepreneurship: Entrepreneurial Management. Strategic Management Journal, 11(5): 17-27. http://dx.doi.org/10.1007/978-3-540-48543-8_7

Teng, B. S. 2007. Corporate entrepreneurship activities through strategic alliances: A Resource-Based Approach toward Competitive Advantage. Journal of Management Studies, 44(1): 119-142. http://dx.doi.org/10.1111/j.1467-6486.2006.00645.x

Thorgren, S., Wincent, J., \& Örtqvist, D. 2012. Unleashing Synergies in Strategic Networks of SMEs: The Influence of Partner Fit on Corporate Entrepreneurship. International Small Business Journal, 30(5): 453-471.

http://dx.doi.org/10.1177/0266242610375292

Turner, T., \& Pennington III, W. W. 2015. Organizational Networks and the Process of Corporate Entrepreneurship: How the Motivation, Opportunity, and Ability to Act Affect Firm Knowledge, Learning, and Innovation. Small Business Economics, 45(2) 447-463. http://dx.doi.org/10.1007/s11187-015-9638-0 


\section{Corporate Entrepreneurship: A Review and Future Research Agenda}

\section{Kamal Sakhdari}

Van de Ven, A. H. 1986. Central Problems in the Management of Innovation. Management Science, 32(5): 590-607. http://dx.doi.org/10.1287/mnsc.32.5.590

Van de Ven, A. H., \& Engleman, R. 2004. Central Problems in Managing Corporate Innovation and Entrepreneurship. In J. Katz \& A. C. Corbett (Eds.), Advances in Entrepreneurship, Firm Emergence and Growth, Volume 7: 47-72. Bingley, United Kingdom: Emerald Group Publishing Limited. http://dx.doi.org/10.1016/S1074-7540\%2804\%2907003-5

Wales, W., Wiklund, J., \& McKelvie, A. 2015. What about New Entry? Examining the Theorized Role of New Entry in the Entrepreneurial Orientation-Performance Relationship. International Small Business Journal, 33(4): 351-373.

http://dx.doi.org/10.1177/0266242613506023

Wang, Y. K. M., Chung, C. C., \& Lim, D. S. 2015. The Drivers of International Corporate Entrepreneurship: CEO Incentive and CEO Monitoring Mechanisms. Journal of World Business, 50(4): 742-753.

http://dx.doi.org/10.1016/j.jwb.2015.02.002

Wei, L. Q., \& Ling, Y. 2015. CEO Characteristics and Corporate Entrepreneurship: Evidence from China. Journal of Business Research, 68(6): 1157-1165.

http://dx.doi.org/10.1016/j.jbusres.2014.11.010

Welter, F. 2011. Contextualizing Entrepreneurship - Conceptual Challenges and Ways Forward. Entrepreneurship Theory and Practice, 35(1): 165-184.

http://dx.doi.org/10.1111/j.1540-6520.2010.00427.x

Wu, J. 2011. Asymmetric Roles of Business Ties and Political Ties in Product Innovation. Journal of Business Research, 64(11): 1151-1156.

http://dx.doi.org/10.1016/j.jbusres.2011.06.014

Yang, Y., Narayanan, V., \& Zahra, S. 2009. Developing the Selection and Valuation Capabilities through Learning: The Case of Corporate Venture Capital. Journal of Business Venturing, 24(3): 261-273.

http://dx.doi.org/10.1016/j.jbusvent.2008.05.001

Yiu, D. W., Lau, C. M., \& Bruton, G. D. 2007. International Venturing by Emerging Economy Firms: The Effects of Firm Capabilities, Home Country Networks, and Corporate Entrepreneurship. Journal of International Business Studies, 38(4): 519-540. http://dx.doi.org/10.1057/palgrave.jibs.8400278

Yiu, D. W., \& Lau, C. M. 2008. Corporate Entrepreneurship as Resource Capital Configuration in Emerging Market Firms. Entrepreneurship Theory and Practice, 32(1): 37-57. http://dx.doi.org/10.1111/j.1540-6520.2007.00215.x

Zaheer, S. 1995. Overcoming the Liability of Foreignness. Academy of Management Journal, 38(2): 341-363. http://dx.doi.org/10.2307/256683

Zahra, S. A. 1991. Predictors and Financial Outcomes of Corporate Entrepreneurship: An Exploratory Study. Journal of Business Venturing, 6(4): 259-285.

http://dx.doi.org/10.1016/0883-9026(91)90019-A
Zahra, S. A. 1993. Environment, Corporate Entrepreneurship, and Financial Performance: A Taxonomic Approach. Journal of Business Venturing, 8(4): 319-340. http://dx.doi.org/10.1016/0883-9026(93)90003-N

Zahra, S. A. 1995. Corporate Entrepreneurship and Financial Performance: The Case of Management Leveraged Buyouts. Journal of Business Venturing, 10(3): 225-247. http://dx.doi.org/10.1016/0883-9026(94)00024-O

Zahra, S. A. 1996. Governance, Ownership, and Corporate Entrepreneurship: The Moderating Impact of Industry Technological Opportunities. Academy of Management Journal, 39(6): 1713-1735. http://dx.doi.org/10.2307/257076

Zahra, S. A. 2007. Contextualizing Theory Building in Entrepreneurship Research. Journal of Business Venturing, 22(3): 443-452. http://dx.doi.org/10.1016/j.jbusvent.2006.04.007

Zahra, S. A. 2015. Corporate Entrepreneurship as Knowledge Creation and Conversion: The Role of Entrepreneurial Hubs. Small Business Economics, 44(4): 727-735. http://dx.doi.org/10.1007/s11187-015-9650-4

Zahra, S. A., \& Covin, J. G. 1995. Contextual Influences on the Corporate Entrepreneurship-Performance Relationship: A Longitudinal Analysis. Journal of Business Venturing, 10(1): 43-58. http://dx.doi.org/10.1016/0883-9026(94)00004-E

Zahra, S. A., Filatotchev, I., \& Wright, M. 2009. How So Threshold Firms Sustain Corporate Entrepreneurship? The Role of Boards and Absorptive Capacity. Journal of Business Venturing, 24(3): 248-260. http://dx.doi.org/10.1016/j.jbusvent.2008.09.001

Zahra, S. A., \& Hayton, J. C. 2008. The Effect of International Venturing on Firm Performance: The Moderating Influence of Absorptive Capacity. Journal of Business Venturing, 23(2): 195-220. http://dx.doi.org/10.1016/j.jbusvent.2007.01.001

Zahra, S. A., Neck, H. M., \& Kelley, D. J. 2004. International Corporate Entrepreneurship and the Evolution of Organizational Competence: A Knowledge-Based Perspective. In J. Katz \& A. C. Corbett (Eds.), Advances in Entrepreneurship, Firm Emergence and Growth, Volume 7: 145-171. Bingley, United Kingdom: Emerald Group Publishing Limited.

http://dx.doi.org/10.1016/S1074-7540(04)07006-0

Zahra, S. A., Neubaum, D. O., \& Huse, M. 2000. Entrepreneurship in Medium-Size Companies: Exploring the Effects of Ownership and Governance Systems. Journal of Management, 26(5): 947-976. http://dx.doi.org/10.1016/S0149-2063(00)00064-7

Zhang, Z., Wan, D., \& Jia, M. 2008. Do High-Performance Human Resource Practices Help Corporate Entrepreneurship? The Mediating role of Organizational Citizenship Behaviour. The Journal of High Technology Management Research, 19(2): 128-138. 


\section{Corporate Entrepreneurship: A Review and Future Research Agenda}

\section{Kamal Sakhdari}

Appendix 1. Key studies on the antecedents of corporate entrepreneurship (Page 1 of 3 )

\begin{tabular}{|c|c|c|c|c|c|}
\hline Authors & Key Results & Antecedent & Theoretical Lens & Measure & Dimensions \\
\hline Zahra (1991) & $\begin{array}{l}\text { Scanning the business } \\
\text { environment promotes } \\
\text { corporate entrepreneurship by } \\
\text { providing relevant knowledge of } \\
\text { industry trends and changes. }\end{array}$ & $\begin{array}{c}\text { Firm/ } \\
\text { environment }\end{array}$ & $\begin{array}{c}\text { Knowledge-type } \\
\text { lens }\end{array}$ & $\begin{array}{c}\text { New survey } \\
\text { scale }\end{array}$ & $\begin{array}{l}\text { Meta-construct } \\
\text { (innovation, } \\
\text { venturing) }\end{array}$ \\
\hline Zahra (1993) & $\begin{array}{l}\text { Environmental hostility and } \\
\text { hospitable business environment } \\
\text { positively affect, and static } \\
\text { environments negatively affect, } \\
\text { corporate entrepreneurship. }\end{array}$ & Environment & Normative theory & $\begin{array}{l}\text { New survey } \\
\text { scale }\end{array}$ & $\begin{array}{c}\text { Individual } \\
\text { (innovation, } \\
\text { venturing, renewal) }\end{array}$ \\
\hline Zahra (1996) & $\begin{array}{l}\text { There is a positive connection } \\
\text { between executive stock } \\
\text { ownership and long-term } \\
\text { institutional ownership, and } \\
\text { corporate entrepreneurship. }\end{array}$ & $\begin{array}{c}\text { Top } \\
\text { management } \\
\text { team }\end{array}$ & Agency theory & $\begin{array}{l}\text { New survey } \\
\text { scale }\end{array}$ & $\begin{array}{c}\text { Individual } \\
\text { (innovation, } \\
\text { venturing, renewal) }\end{array}$ \\
\hline $\begin{array}{l}\text { Zahra, } \\
\text { Neubaum, and } \\
\text { Huse }(2000)\end{array}$ & $\begin{array}{l}\text { Executives and outside directors' } \\
\text { stock ownership, being different } \\
\text { persons and the medium size of } \\
\text { the board positively influence } \\
\text { corporate entrepreneurship. }\end{array}$ & $\begin{array}{c}\text { Top } \\
\text { management } \\
\text { team }\end{array}$ & Agency theory & $\begin{array}{c}\text { Adding } \\
\text { international } \\
\text { venturing }\end{array}$ & $\begin{array}{c}\text { Individual } \\
\text { (innovation, local } \\
\text { and international } \\
\text { venturing) }\end{array}$ \\
\hline Hayton (2005) & $\begin{array}{l}\text { Diversity of human capital in top } \\
\text { management team (facilitating } \\
\text { knowledge acquisition and } \\
\text { triggering learning) enhances } \\
\text { corporate entrepreneurship. }\end{array}$ & $\begin{array}{c}\text { Top } \\
\text { management } \\
\text { team/firm }\end{array}$ & $\begin{array}{c}\text { Knowledge-based } \\
\text { view }\end{array}$ & Zahra (1996) & $\begin{array}{l}\text { Individual } \\
\text { (innovation, } \\
\text { venturing) }\end{array}$ \\
\hline $\begin{array}{l}\text { Kellermanns } \\
\text { and Eddleston } \\
(2006)\end{array}$ & $\begin{array}{l}\text { Willingness to change, } \\
\text { generational involvement, and } \\
\text { perceived technological } \\
\text { opportunities increase corporate } \\
\text { entrepreneurship in family } \\
\text { business. }\end{array}$ & Firm & $\begin{array}{c}\text { Entrepreneurial } \\
\text { thinking }\end{array}$ & Zahra (1996) & $\begin{array}{c}\text { Meta-construct } \\
\text { (innovation, } \\
\text { venturing, renewal) }\end{array}$ \\
\hline $\begin{array}{l}\text { Yiu, Lau, and } \\
\text { Bruton ( 2007) }\end{array}$ & $\begin{array}{l}\text { Firm-level ownership advantages } \\
\text { (such as business and } \\
\text { institutional ties) foster } \\
\text { corporate entrepreneurship. }\end{array}$ & $\begin{array}{c}\text { Firm/ } \\
\text { environment }\end{array}$ & $\begin{array}{c}\text { Knowledge-based } \\
\text { view }\end{array}$ & $\begin{array}{c}\text { Zahra (1996), } \\
\text { Zahra et al. } \\
(2000)\end{array}$ & $\begin{array}{c}\text { Individual } \\
\text { (innovation, local } \\
\text { and international } \\
\text { venturing, renewal) }\end{array}$ \\
\hline Simsek (2007) & $\begin{array}{l}\text { Risk-taking propensity and } \\
\text { pursuit of entrepreneurial } \\
\text { initiative mediate the } \\
\text { relationship between CEO tenure } \\
\text { and performance. }\end{array}$ & $\begin{array}{c}\text { Top } \\
\text { management } \\
\text { team }\end{array}$ & $\begin{array}{l}\text { Upper echelons } \\
\text { perspective }\end{array}$ & Zahra (1996) & $\begin{array}{c}\text { Meta-construct } \\
\text { (innovation, } \\
\text { venturing, renewal) }\end{array}$ \\
\hline
\end{tabular}




\section{Corporate Entrepreneurship: A Review and Future Research Agenda}

\section{Kamal Sakhdari}

Appendix 1. Key studies on the antecedents of corporate entrepreneurship (Page 2 of 3 )

\begin{tabular}{|c|c|c|c|c|c|}
\hline Authors & Key Results & Antecedent & Theoretical Lens & Measure & Dimensions \\
\hline $\begin{array}{l}\text { Simsek, Veiga, } \\
\text { and Lubatkin } \\
(2007)\end{array}$ & $\begin{array}{l}\text { Discretionary slack mediates the } \\
\text { relationship between } \\
\text { environmental perceptions and } \\
\text { corporate entreprencurship. The } \\
\text { relationship between } \\
\text { discretionary slack and corporate } \\
\text { entrepreneurship is moderated } \\
\text { by market sensing capacity. }\end{array}$ & $\begin{array}{c}\text { Firm/ } \\
\text { environment }\end{array}$ & $\begin{array}{l}\text { Organizational/ } \\
\text { agency theories }\end{array}$ & Zahra (1996) & $\begin{array}{l}\text { Meta-construct } \\
\text { (innovation, } \\
\text { venturing, renewal) }\end{array}$ \\
\hline $\begin{array}{l}\text { Ling, Simsek, } \\
\text { Lubatkin, and } \\
\text { Veiga (2008) }\end{array}$ & $\begin{array}{l}\text { CEO transactional leadership } \\
\text { through enhancing top } \\
\text { management team's behavioural } \\
\text { integration, risk propensity, and } \\
\text { decentralization affects } \\
\text { corporate entrepreneurship. }\end{array}$ & $\begin{array}{c}\text { Top } \\
\text { management } \\
\text { team }\end{array}$ & Leadership theory & Zahra (1996) & $\begin{array}{l}\text { Meta-construct } \\
\text { (innovation, } \\
\text { venturing, renewal) }\end{array}$ \\
\hline $\begin{array}{l}\text { Yiu and Lau } \\
(2008)\end{array}$ & $\begin{array}{l}\text { Political, social, and reputational } \\
\text { capital foster corporate } \\
\text { entrepreneurship and relative } \\
\text { performance. }\end{array}$ & Firm & $\begin{array}{c}\text { Knowledge-based } \\
\text { view }\end{array}$ & $\begin{array}{l}\text { Zahra et al. } \\
\text { (2000) }\end{array}$ & $\begin{array}{l}\text { Individual } \\
\text { (innovation, local } \\
\text { and international } \\
\text { venturing) }\end{array}$ \\
\hline $\begin{array}{l}\text { Simsek, } \\
\text { Lubatkin, Veiga, } \\
\text { and Dino (2009) }\end{array}$ & $\begin{array}{l}\text { An entrepreneurial alert } \\
\text { information system that provides } \\
\text { relevant information in a timely } \\
\text { and pro-active manner fosters } \\
\text { corporate entrepreneurship. }\end{array}$ & Firm & $\begin{array}{c}\text { Knowledge-based } \\
\text { view }\end{array}$ & Zahra (1996) & $\begin{array}{c}\text { Meta-construct } \\
\text { (innovation, } \\
\text { venturing, renewal) }\end{array}$ \\
\hline $\begin{array}{l}\text { Heavy, Simsek, } \\
\text { Roche, and Kelly } \\
(2009)\end{array}$ & $\begin{array}{l}\text { Managerial uncertainty } \\
\text { preference and environmental } \\
\text { dynamism moderate the } \\
\text { relationship between decision } \\
\text { comprehensiveness and } \\
\text { corporate entrepreneurship. }\end{array}$ & $\begin{array}{l}\text { Top } \\
\text { management } \\
\text { team/ } \\
\text { environment }\end{array}$ & $\begin{array}{l}\text { Strategic decision- } \\
\text { making theory }\end{array}$ & Zahra (1996) & $\begin{array}{l}\text { Meta-construct } \\
\text { (innovation, } \\
\text { venturing, renewal) }\end{array}$ \\
\hline $\begin{array}{l}\text { Romero- } \\
\text { Martinez et al. } \\
(2010)\end{array}$ & $\begin{array}{l}\text { Privatization improves corporate } \\
\text { entrepreneurship when firms are } \\
\text { operating in highly competitive } \\
\text { industries. }\end{array}$ & $\begin{array}{c}\text { Firm/ } \\
\text { environment }\end{array}$ & Agency theory & Zahra (1996) & $\begin{array}{c}\text { Meta-construct } \\
\text { (innovation, } \\
\text { venturing, renewal) }\end{array}$ \\
\hline $\begin{array}{l}\text { Thorgren, } \\
\text { Wincent, and } \\
\text { Örtqvist (2012) }\end{array}$ & $\begin{array}{l}\text { Relational capital among } \\
\text { partners through knowledge } \\
\text { transfer promotes corporate } \\
\text { entrepreneurship. }\end{array}$ & Firm & $\begin{array}{c}\text { Knowledge-based } \\
\text { view }\end{array}$ & Zahra (1996) & $\begin{array}{l}\text { Meta-construct } \\
\text { (innovation, } \\
\text { venturing, renewal) }\end{array}$ \\
\hline $\begin{array}{l}\text { Heavey and } \\
\text { Simsek (2013) }\end{array}$ & $\begin{array}{l}\text { Top management team's size, } \\
\text { diversity, and network size raise } \\
\text { the level of corporate } \\
\text { entrepreneurship. }\end{array}$ & $\begin{array}{c}\text { Top } \\
\text { management } \\
\text { team/environ } \\
\text { ment }\end{array}$ & $\begin{array}{c}\text { Knowledge-based } \\
\text { view }\end{array}$ & Zahra (1996) & $\begin{array}{l}\text { Meta-construct } \\
\text { (innovation, } \\
\text { venturing, renewal) }\end{array}$ \\
\hline
\end{tabular}




\section{Corporate Entrepreneurship: A Review and Future Research Agenda}

\section{Kamal Sakhdari}

Appendix 1. Key studies on the antecedents of corporate entrepreneurship (Page 3 of 3 )

\begin{tabular}{|c|c|c|c|c|c|}
\hline Authors & Key Results & Antecedent & Theoretical Lens & Measure & Dimensions \\
\hline $\begin{array}{l}\text { Burgers and } \\
\text { Covin (2014) }\end{array}$ & $\begin{array}{l}\text { Structural differentiation affects } \\
\text { corporate entrepreneurship, } \\
\text { moderated by environmental } \\
\text { dynamism and firm size. }\end{array}$ & Firm & $\begin{array}{c}\text { Structural } \\
\text { contingency } \\
\text { theory }\end{array}$ & Zahra (1996) & $\begin{array}{l}\text { Meta-construct } \\
\text { (innovation, } \\
\text { venturing, renewal) }\end{array}$ \\
\hline $\begin{array}{l}\text { Wei and Ling } \\
(2015)\end{array}$ & $\begin{array}{l}\text { CEO characteristics impact } \\
\text { corporate entrepreneurship. }\end{array}$ & $\begin{array}{c}\text { Top } \\
\text { management } \\
\text { team }\end{array}$ & $\begin{array}{l}\text { Human and social } \\
\text { capital theories }\end{array}$ & Zahra (1996) & $\begin{array}{c}\text { Meta-construct } \\
\text { (innovation, } \\
\text { venturing, renewal) }\end{array}$ \\
\hline $\begin{array}{l}\text { Turner and } \\
\text { Pennington III, } \\
\text { 2015) }\end{array}$ & $\begin{array}{l}\text { The greater the ability, } \\
\text { motivation, and opportunity for } \\
\text { knowledge sharing through } \\
\text { enhancing learning in an } \\
\text { organizational network can } \\
\text { enhance innovation. }\end{array}$ & $\begin{array}{l}\text { Dyad/ } \\
\text { network }\end{array}$ & $\begin{array}{c}\text { Knowledge-based } \\
\text { view }\end{array}$ & New scale & $\begin{array}{l}\text { Single dimension of } \\
\text { innovation }\end{array}$ \\
\hline
\end{tabular}

\begin{tabular}{|c|c|c|c|c|c|}
\hline $\begin{array}{l}\text { Glaser, Fourné, } \\
\text { and Elfring } \\
(2015)\end{array}$ & $\begin{array}{l}\text { Top managers spanning ties } \\
\text { increase exploratory innovation. }\end{array}$ & $\begin{array}{c}\text { Top } \\
\text { management }\end{array}$ & $\begin{array}{l}\text { Social network } \\
\text { theory }\end{array}$ & $\begin{array}{l}\text { Jansen et al. } \\
\qquad(2006)\end{array}$ & $\begin{array}{l}\text { Single dimension of } \\
\text { innovation }\end{array}$ \\
\hline $\begin{array}{l}\text { Nason, } \\
\text { McKelvie, and } \\
\text { Lumpkin (2015) }\end{array}$ & $\begin{array}{l}\text { Firms of different sizes use } \\
\text { corporate entrepreneurship for } \\
\text { different purposes. }\end{array}$ & Firm & $\begin{array}{c}\text { Resource-based } \\
\text { view }\end{array}$ & Meta-analysis & $\begin{array}{c}\text { Different } \\
\text { dimensions } \\
\text { (innovation, } \\
\text { venturing, renewal) }\end{array}$ \\
\hline $\begin{array}{l}\text { Naldi, } \\
\text { Achtenhagen, } \\
\text { and Davidsson, } \\
\text { (2015) }\end{array}$ & $\begin{array}{l}\text { Different dimensions of } \\
\text { entrepreneurial management } \\
\text { differently affect SMEs' } \\
\text { international venturing. }\end{array}$ & $\begin{array}{l}\text { Top } \\
\text { management } / \\
\text { firm }\end{array}$ & $\begin{array}{l}\text { Stevenson's theory } \\
\text { of entrepreneurial } \\
\text { management }\end{array}$ & $\begin{array}{l}\text { Zahra et al. } \\
\qquad(2000)\end{array}$ & $\begin{array}{l}\text { Single dimension of } \\
\text { international } \\
\text { corporate } \\
\text { venturing. }\end{array}$ \\
\hline $\begin{array}{l}\text { Behrens and } \\
\text { Patzelt (2015) }\end{array}$ & $\begin{array}{l}\text { Past project failure experience, } \\
\text { the firm's growth rate, and } \\
\text { hierarchical level impact } \\
\text { managers' decisions on } \\
\text { terminating corporate } \\
\text { entrepreneurship projects. }\end{array}$ & $\begin{array}{l}\text { Top } \\
\text { management/ } \\
\text { firm }\end{array}$ & $\begin{array}{l}\text { Attention-based } \\
\text { view }\end{array}$ & Zahra (1996) & $\begin{array}{c}\text { Corporate } \\
\text { entrepreneurship } \\
\text { projects } \\
\text { (innovation, } \\
\text { venturing, renewal) }\end{array}$ \\
\hline $\begin{array}{l}\text { Wang, Chung, } \\
\text { and Lim (2015) }\end{array}$ & $\begin{array}{l}\text { The alignment of CEO incentives } \\
\text { with shareholder interests and } \\
\text { adoption of CEO monitoring } \\
\text { mechanisms will enhance } \\
\text { international corporate } \\
\text { entrepreneurship }\end{array}$ & $\begin{array}{l}\text { Top } \\
\text { management } / \\
\text { firm }\end{array}$ & Agency theory & New scale & $\begin{array}{l}\text { Single dimension of } \\
\text { international } \\
\text { corporate } \\
\text { venturing. }\end{array}$ \\
\hline
\end{tabular}

Citation: Sakhdari, K. 2016. Corporate Entrepreneurship: A Review and Future Research Agenda. Technology Innovation Management Review, 6(8): 5-18. http://timreview.ca/article/1007 